\title{
Relative Proliferation of Gullies on Three Geological Sediments: The Influence of Soil Consistency Limits and Shear Strength
}

\author{
Louis A. Oparaku ${ }^{1}$, Raphael T. Iwar' ${ }^{1}$ Joseph E. Edeh ${ }^{2}$ \\ ${ }^{1}$ Department of Agricultural and Environmental Engineering, University of Agriculture, Makurdi, Nigeria \\ ${ }^{2}$ Department of Civil Engineering, University of Agriculture, Makurdi, Nigeria \\ Email: *alimonu2013@gmail.com
}

How to cite this paper: Oparaku, L.A., Iwar, R.T. and Edeh, J.E. (2018) Relative Proliferation of Gullies on Three Geological Sediments: The Influence of Soil Consistency Limits and Shear Strength. Journal of Environmental Protection, 9, 25-33. https://doi.org/10.4236/jep.2018.91003

Received: December 1, 2017

Accepted: January 13, 2018

Published: January 16, 2018

Copyright ( $) 2018$ by authors and Scientific Research Publishing Inc. This work is licensed under the Creative Commons Attribution International License (CC BY 4.0).

http://creativecommons.org/licenses/by/4.0/

\begin{abstract}
This study was carried out to evaluate the influence of soil consistency limits and shear strength on the relative proliferation of gullies on three geological sediments, namely: the Upper Coal Measures (UCM), the Ajalli Sandstones (AS), and the Lower Coal Measures (LCM), which has been ranked as AS > UCM > LCM. Soil samples were collected from a depth range of $60-90 \mathrm{~cm}$ of sampling pits dug at a selected location on each of these texturally homogenous and unique formations. These were analysed for consistency limits and shear strength using standard methods and procedures. Results showed that the plasticity index (PI) of the UCM $\left(\mathrm{PI}_{\mathrm{UCM}}\right)$ was $24.49 \%$; $\mathrm{PI}_{\mathrm{AS}}, 5.89 \%$; and $\mathrm{PI}_{\mathrm{LCM}}, 44.85 \%$. The shear strength (S) of the UCM $\left(\mathrm{S}_{\mathrm{UCM}}\right)$ was $314.74 \mathrm{KN} / \mathrm{m}^{2}$; $\mathrm{S}_{\mathrm{AS}}, 196.23 \mathrm{KN} / \mathrm{m}^{2}$; and $\mathrm{S}_{\mathrm{LCM}}, 321.72 \mathrm{KN} / \mathrm{m}^{2}$. The results of the study show that rankings of the respective contributions of these two geotechnical properties to the vulnerability of the sediments to gully (soil) erosion follow the same order of proliferation of gullies on the plateau landscape: AS > UCM > LCM. Hence, consistency limits and shear strength parameters partly influence and explain the relative proliferation of gullies on the three formations. Further studies are required to determine other soil factors of gully erosion in the area in order to evolve appropriate management strategies for these sediments.
\end{abstract}

\section{Keywords}

Relative, Vulnerability, Proliferation, Fragility

\section{Introduction}

Gullies proliferate the landscape of the Idah-Ankpa Plateau (IAP) of the Anambra 
Basin, Nigeria, which is underlain $100 \%$ by three geological sediments [1]. These geological sediments comprise the Upper Coal Measures (UCM) (36\%), the Ajalli Sandstones (AS) (44\%), and the Lower Coal Measures (LCM) (20\%) (Figure 1). [2] estimated that about 100 gullies were in occurrence on the UCM, 740 on the AS, and only one on the LCM. So that the proliferation of gullies on the IAP can be ranked as AS > UCM > LCM. He noted that the relative proliferation of gullies on these geological units bears a relationship with the vulnerability to erosion of the sediments of which each unit is composed.

Soil erodibility is a measure of a soil's vulnerability to erosion [3]. When two or more soils located in the same ecological region are exposed to the same management practices, they suffer different amounts of erosion which are attributable to their inherent erodibility [3]. [4] identified the different soil factors that influence erodibility to include texture, structure, aggregate stability, shear strength, permeability, infiltration capacity, organic matter, and other chemical properties.

Soil erosion studies on the IAP are few and these have been concentrated on the AS. [1] [5] stated that each of the geological units underlying the plateau landscape is texturally uniform and unique. [5] [6] noted that most gully erosion

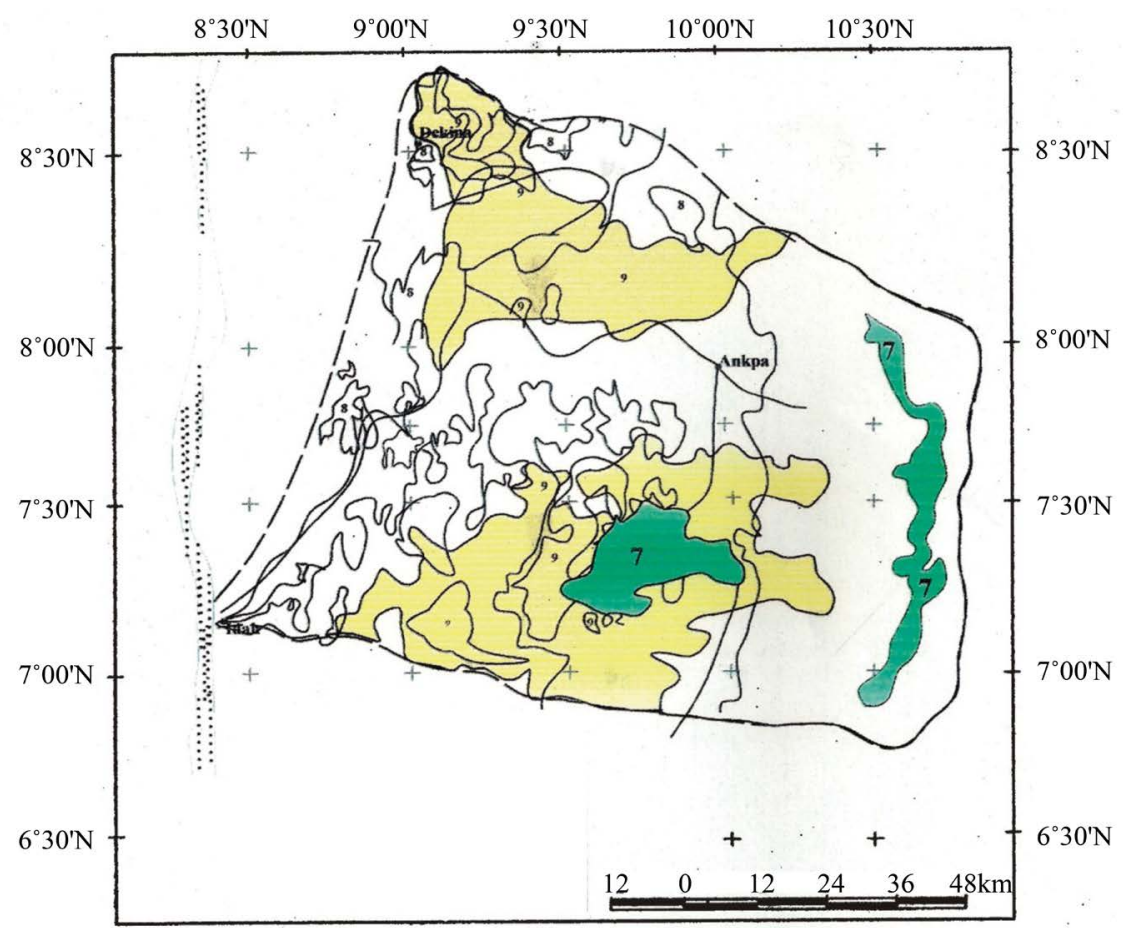

\begin{tabular}{|c|l|}
\hline$\odot$ & Town \\
\hline- & Study Area Boundary \\
\hline- & Roads \\
\hline Q & Upper Coal Measures \\
\hline S & Lower Coal Measures \\
\hline$\&$ & Ajalli sandstones \\
\hline- & Rivers \\
\hline
\end{tabular}

Figure 1. Geological map of the Idah-Ankpa Plateau. 
sites in the southeastern states of Nigeria are located either on the Nanka Sands or the Ajalli Sandstones. They observed that these two geological formations bear striking textural similarities from the gully erosion point of view. [2] [7] reported that gully erosion processes on the IAP are localized on the fine-tomedium grained AS sediments of the Anambra Basin region.

The geological causes of the proliferation of gullies at Ankpa, a growing semiurban town located on the AS, was the subject of investigation by [8]. After a numerical study and statistical analysis of the orientation of the gullies and surface cracks, they compared the pattern of the gullies with joint orientation measurements and came to the conclusion that the gullies resulted from neotectonic forces since the joints were found in recent laterites. These geological processes were also reported and confirmed by [9] as the principal causes of gullies in the southeastern states of Nigeria. Nevertheless, these investigators seemed to have ignored the influence of soil geotechnical and textural properties in the evolution of the gullies. [10] assessed the influence of soil texture on the vulnerability to erosion of the three geological sediments and found that texture plays a substantial role in the relative proliferation of gullies on the sediments.

However, studies and data on the geotechnical properties of each of the geological sediments, especially the UCM and the LCM, are lacking. Availability of these data is required to explain the relative proliferation of gullies on these sediments. This study, therefore, was a part attempt to satisfy this need. The consistency limits and shear strength of the three geological units were determined to assess their roles as factors influencing the disproportionate differentials in the proliferation of gullies on the plateau landscape.

\section{The Study Area}

The Idah-Ankpa Plateau (IAP) of the Anambra Basin of Nigeria comprises the Western Ankpa Plateau and the Idah Flood Plains. It has been so named because the latter consists of an insignificant percentage of the whole area [11]. Nestled in the Guinea Savannah ecological zone of Nigeria, it lies between Latitudes $7^{\circ} 17^{\prime} 00^{\prime \prime} \mathrm{N}$ and $7^{\circ} 23^{\prime} 30^{\prime \prime} \mathrm{N}$ and Longitudes $8^{\circ} 20^{\prime} 20^{\prime} \mathrm{E}$ and $9^{\circ} 00^{\prime} 00^{\prime \prime} \mathrm{E}$. Parts of Kogi and Benue States are the only land areas encompassed by the IAP. The underlying geology consists of cretaceous sediments made up of the UCM, the AS, and the LCM. [1] reported that the geological succession of these sediments is as follows: UCM-AS-LCM, that is, the UCM is the overlying formation, the LCM the underlying formation, while the AS is sandwiched in between the two (Figure 2 ). The AS is exposed to the erosive processes of the elements at locations where the UCM, which provides a protective overburden, has been denuded away by natural geologic processes. And where both the UCM and the AS have been eroded away, the LCM becomes exposed to erosion [1]. A full description of other environmental aspects of the study area is detailed in [12].

\subsection{Materials and Methods}

Notably, the textural homogeneity and uniqueness of each unit of the three 


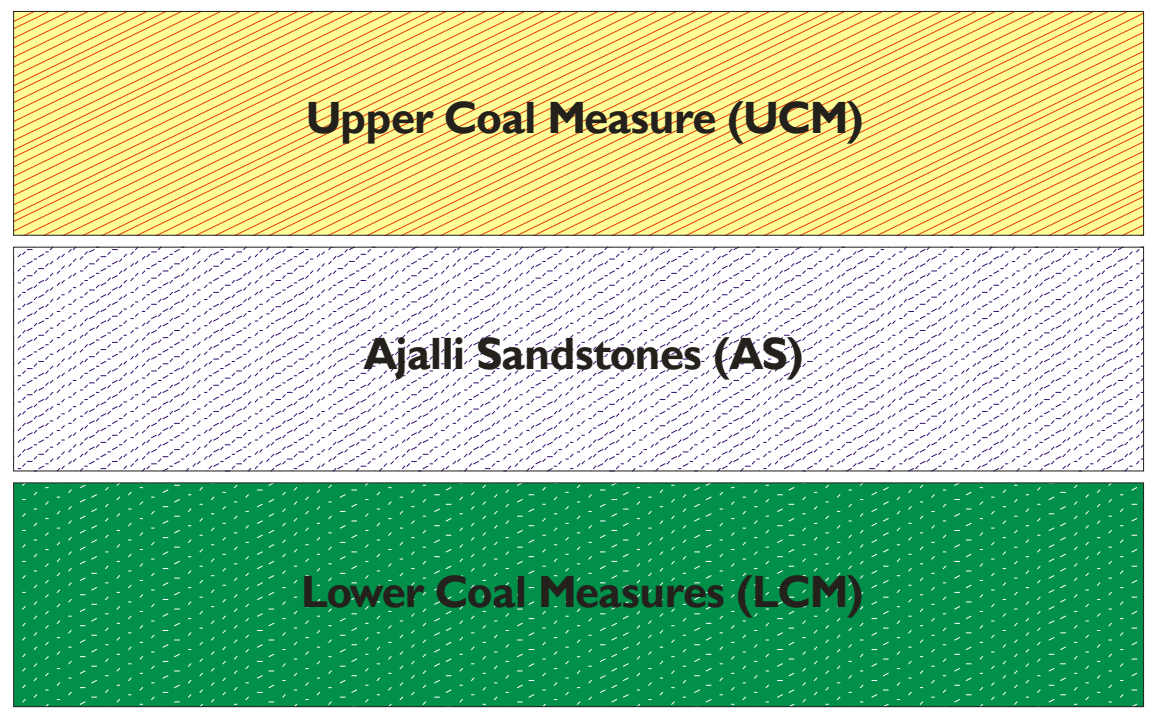

Figure 2. Geological succession of the three sediments underlying the Idah-Ankpa Plateau.

geological sediments have been established [1] [5]. In addition, an assessment of the textural characteristics of the sediments showed that the proliferation of gullies on each unit was related to its vulnerability to erosion, which was ranked as AS > UCM > LCM [10]. Therefore, to assess the influence of consistency limits and shear strength on the vulnerability to erosion of the sediments in order to explain their roles in the relative proliferation of gullies on these units, sampling pits were dug up to a depth of $90 \mathrm{~cm}$ at a selected location on each unit. Soil samples were then collected from the $60-90 \mathrm{~cm}$ depth range for laboratory investigations. The $60-90 \mathrm{~cm}$ (and above) depth range was assumed to represent the depth up to which a rill expands before a gully is said to have occurred. [13] defined a gully as any earth channel conveying ephemeral flows at a depth greater than $60 \mathrm{~cm}$.

The samples were subjected to consistency limits tests to determine their liquid limits, plastic limits, and plasticity indices. The Cassagrande apparatus was used in the determination of the liquid limits while the plastic limits were obtained using the glass surface/palm rolling method. The shear strength was determined using the direct shear box apparatus.

\subsection{Theoretical Frameworks}

\subsubsection{Consistency Limits}

When water is removed from a fine-grained soil, it passes through a number of states, namely: liquid, plastic, semi-solid, and solid. The moisture contents of the soil as it passes from one state to the other are known as the consistency limits. The range of moisture contents over which the soil is liquid is known as the liquid limit index, and the range over which it is plastic is the plastic limit index. The plasticity index is derived as:

$$
\mathrm{PI}=\mathrm{LL}-\mathrm{PL}
$$


where PI = Plasticity index

$\mathrm{LL}=$ Liquid limit index

$\mathrm{PL}=$ Plastic limit index

It is well known that a soil with a higher PI is more resistant to erosion than one with a lower value [14] [15]. This is because a higher PI is indicative of the presence of fine soil-binding materials that increase its cohesion and hence reduce its erodibility. Non-plastic soils have low water-retaining capacities and, consequently, have high water-transmission capacities. They encourage rapid infiltration and percolation rather than surface runoff. However, on non-plastic soils, once runoff has occurred to incise the soil to an appreciable depth, percolating water will act to weaken the soil's resistance to shear failure both at the sides and at the heads carp of the incision, leading to mass wasting that result in the growth and expansion of a gully. [15] stated that a fine-grained soil is considered highly plastic and resistant to erosion if the PI is greater than $50 \%$. The plasticity is low and the soil is considered erodible if the PI is less than $40 \%$.

\subsubsection{Shear Strength}

The shear strength of a soil is determined using a direct shear box apparatus and is computed as follows:

$$
S=C+\sigma \tan \Phi
$$

where, $S=$ shear strength

$$
C=\text { cohesion }
$$$$
\Phi=\text { soil's angle of internal friction }
$$$$
\sigma=\text { normal stress }
$$

$$
\sigma=\frac{N}{\text { Surface area of ring }}
$$

where, $N=$ vertical load.

The shear strength of a soil is influenced by cohesion, the normal stress acting in the soil, and the angle of internal friction. The cohesion is determined by the amount of binding materials, such as clay and organic matter, present in the soil, and the normal stress is dependent on the imposed vertical load. The growth of a gully is controlled by the shear strength of the soil [4] [16].

\section{Results and Discussion}

\subsection{Consistency Limits (Plasticity Indices, PI)}

The results of laboratory tests carried out to determine the plasticity indices (PI) of the three geological sediments are shown in Table 1. The PI of the AS was $5.89 \%, \mathrm{UCM}=24.49 \%$, and the LCM $=44.85 \%$. The PI of the AS and UCM falls below $40 \%$, which is the [15] upper limit for non-plastic soils. However, the PI of the UCM is greater than that of the AS, which is an indication that the UCM is more cohesive and, therefore, more resistant to erosion than the AS. On the other hand, a PI of $5.89 \%$ is indicative of the paucity of soil binding materials in the AS. 
Table 1. Locations and results of the consistency limits tests for the three geological Sediments Underlying the Idah-Ankpa Plateau (IAP).

\begin{tabular}{|c|c|c|c|}
\hline $\begin{array}{l}\text { Location and consistency } \\
\text { limits }\end{array}$ & $\begin{array}{l}\text { Ajalli Sandstones (AS) } \\
\text { (60 - } 90 \mathrm{~cm} \text { depth) }\end{array}$ & $\begin{array}{c}\text { Upper Coal Measures } \\
\text { (UCM) } \\
(60-90 \mathrm{~cm} \text { depth })\end{array}$ & $\begin{array}{c}\text { Lower Coal Measures } \\
\text { (LCM) } \\
(60-90 \mathrm{~cm} \text { depth })\end{array}$ \\
\hline Location & Ankpa & Dekina & Owukpa \\
\hline Liquid limit (\%) & 24.61 & 44.00 & 66.50 \\
\hline Plastic limit (\%) & 18.72 & 19.51 & 21.65 \\
\hline Plasticity index (\%) & 5.89 & 24.49 & 33.85 \\
\hline
\end{tabular}

The 5.89\% PI value of the AS betrays its sandy, erodible nature. Although sandy soils are generally and characteristically non-plastic, [17] reported that the PI of some soil samples collected from the heads carp of the AguluNanka gully was as low as $8.5 \%$, whereas the mean PI of soil samples collected from a depth of two metres along gully walls in the gullied areas of the Udi-Nsukkascarp was zero percent [14]. Evidently, the PI value obtained for the AS in this study is consistent with typical values for erodible soils. The indication again is that the AS has higher infiltration and permeability, sheds less runoff on the surface and, therefore, is more erodible than the UCM.

The PI of the LCM is the highest with a value (44.85\%) greater than $40 \%$ and, therefore, can be rated as plastic. It retains the highest amount of water, transmits the least water through its sediments, sheds the highest amount of runoff, and is obviously the least erodible of the three formations. The ranking of the PI values of the three sediments can, therefore, be expressed as $\mathrm{PI}_{\mathrm{AS}}<\mathrm{PI}_{\mathrm{UCM}}<\mathrm{PI}_{\mathrm{LCM}}$. Because PI is inversely related to soil erodibility, the vulnerability to erosion of the three geological sediments can be expressed as AS > UCM > LCM. This agrees with the ranking of the relative proliferation of gullies on the IAP stated in the introduction (AS > UCM > LCM). The study clearly shows that the wide differences in the PI values of the sediments are factors that partly influence and explain the relative proliferation of gullies on the Idah-Ankpa Plateau (IAP).

\subsection{Shear Strength}

The angle of internal friction $(\Phi)$ in the AS is the highest with a value of $37.20^{\circ}$, and the LCM has the least $\left(19.23^{\circ}\right)$, followed by the UCM $\left(22.36^{\circ}\right)$ (Table 2 and Figure 3). Compared to the AS, the low $\Phi$ values in the LCM and UCM indicate lower particle interlocking and particle to particle sliding during Shear. The value of $\Phi$ in the AS formation evidences its high interlocking properties. The $\Phi$ value in a soil is influenced by its physical, chemical and mineralogical properties [16] [18].

However, the low value of cohesion, $\mathrm{C}$, in the AS $\left(24.22 \mathrm{KN} / \mathrm{m}^{2}\right)$ confirms the paucity of binding materials in the sediments. The UCM has a higher value $\left(74.52 \mathrm{KN} / \mathrm{m}^{2}\right)$, while the LCM has the highest $\left(110.34 \mathrm{KN} / \mathrm{m}^{2}\right)$. Soil cohesion is affected by the amount of binding materials present in the soil, such as clay and organic matter $(\mathrm{OM})$. The more the binding materials, the higher is the soil's 
Table 2. Locations and results of shear strength test for the three geological sediments Underlying the Idah Ankpa Plateau (IAP).

\begin{tabular}{cccc}
\hline Location and shear parameters & $\begin{array}{c}\text { Ajalli Sandstones (AS) } \\
(60-90 \mathrm{~cm} \text { depth) }\end{array}$ & $\begin{array}{c}\text { Upper Coal Measures Lower Coal Measures } \\
(\mathrm{UCM})\end{array}$ \\
\hline Location & Ankpa & Dekina & $\begin{array}{c}\text { (LCM }) \\
(60-90 \mathrm{~cm} \text { depth })\end{array}$ \\
$\Phi$ & $37.20^{\circ}$ & $22.36^{\circ}$ & 19.23 \\
C $\left(\mathrm{KN} / \mathrm{m}^{2}\right)$ & 24.22 & 74.52 & 110.34 \\
Shear strength, & & & 321.72 \\
$\mathrm{~S}$, value $\left(\mathrm{KN} / \mathrm{m}^{2}\right)$ & 196.23 & 314.74 & \\
\hline
\end{tabular}

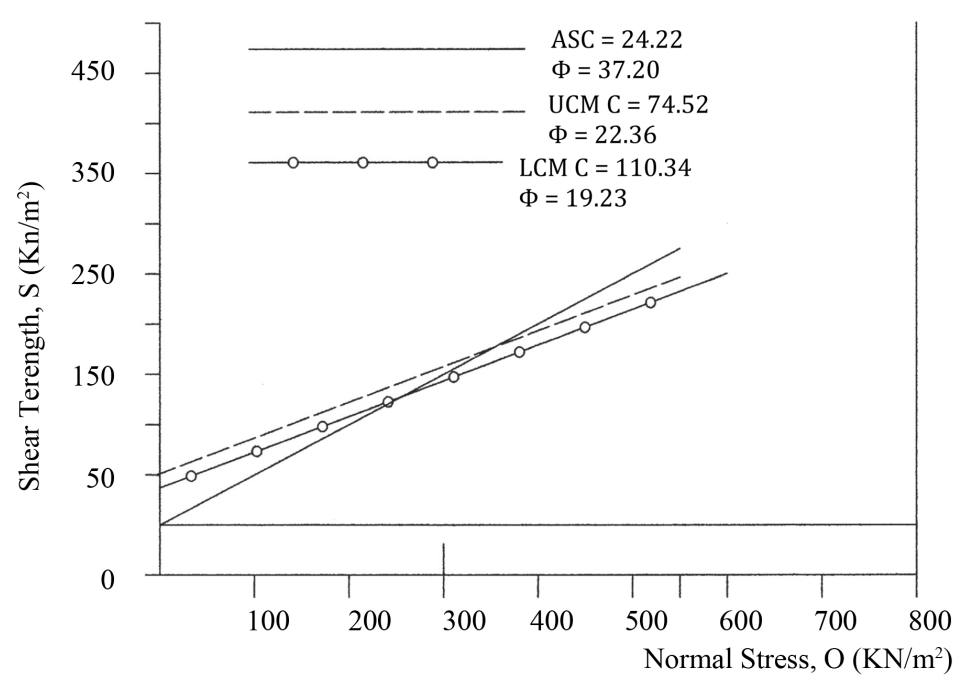

Figure 3. Results of the Triaxial Tests for the Three Geological Formations. $\mathrm{C}$ represents cohesion ( $\mathrm{Y}$ intercept) and $\Phi$ is the angle of internal friction (slope of line).

C-value. In a study of the textural characteristics of the sediments of the IAP, [2] reported that the mean clay and OM contents of the sediments at a depth range of $60-90 \mathrm{~cm}$ were AS, $18 \%$ and $0.63 \%$; UCM, $36 \%$ and $1.19 \%$; and LCM, $41 \%$ and $1.38 \%$ respectively. The low presence of binding materials in the AS also explains why it has the lowest shear strength, AS $\left(196.23 \mathrm{KN} / \mathrm{m}^{2}\right)$. This is followed by the UCM $\left(314.74 \mathrm{KN} / \mathrm{m}^{2}\right)$, and the LCM has the highest $\left(321.72 \mathrm{KN} / \mathrm{m}^{2}\right)$.

Therefore, results of the triaxial shear tests show that the $\Phi$-values of the three sediments follow the same order of vulnerability to erosion of the sediments: $\Phi_{\mathrm{AS}}>\Phi_{\mathrm{UCM}}>\Phi_{\mathrm{LCM}}$. On the other hand, the cohesion (C) and the shear strength (S) follow reverse orders of increase of the soils' vulnerability to erosion: $\mathrm{C}_{\mathrm{AS}}<$ $\mathrm{C}_{\mathrm{UCM}}<\mathrm{C}_{\mathrm{LCM}}$ and $\mathrm{S}_{\mathrm{AS}}<\mathrm{S}_{\mathrm{UCM}}<\mathrm{S}_{\mathrm{LCM}}$ respectively. Since the $\mathrm{C}$ and $\mathrm{S}$ values are inverse functions of the erodibility of the sediments, the rankings agree with the relative vulnerability to erosion of the sediments and, hence, the resulting order of proliferation of gullies on the IAP: AS > UCM > LCM.

The study again shows that the angle of internal friction, $\Phi$, the cohesion, C, and the shear strength, $\mathrm{S}$, of the sediments are soil geotechnical properties that partly influence and explain the relative proliferation of gullies on the geological 
sediments of the IAP.

\section{Conclusions and Recommendations}

This study leads to the following conclusions:

1) The plasticity indices of the geological sediments of the Idah-Ankpa Plateau can be ranked as $\mathrm{Pl}_{\mathrm{AS}}<\mathrm{Pl}_{\mathrm{UCM}}<\mathrm{Pl}_{\mathrm{LCM}}$.

2) Because $\mathrm{Pl}$ is inversely related to soil erodibility, the vulnerability to erosion of the sediments can be ranked as AS > UCM > LCM based on the PI criterion.

3) The angle of internal friction, $\Phi$, is ranked as $\Phi_{\mathrm{AS}}>\Phi_{\mathrm{UCM}}>\Phi_{\mathrm{LCM}}$. Since $\Phi$ is directly related to soil erodibility, the vulnerability of the sediments to erosion based on the $\Phi$ factor can be ranked as AS > UCM > LCM.

4) Soil cohesion (C) and shear strength, $S$, are each inversely proportional to soil erodibility and are respectively ranked as $\mathrm{C}_{\mathrm{AS}}<\mathrm{C}_{\mathrm{UCM}}<\mathrm{C}_{\mathrm{LCM}}$ and $\mathrm{S}_{\mathrm{As}}<\mathrm{S}_{\mathrm{UCM}}<$ $\mathrm{S}_{\mathrm{LCM}}$.

5) Based on the $C$ and $S$ criteria, the vulnerability to erosion of the sediments can be ranked as AS > UCM > LCM.

6) Therefore, the consistency limits and shear strength of the sediments partly influence and explain the relative proliferation of gullies on the three geological formations underlying the IAP.

Further studies are needed to investigate other soil factors that influence the relative proliferation of gullies on these sediments. Management practices adopted for each of these sediments should reflect their relative fragility.

\section{References}

[1] Preez, J.W. and Barber, W. (1965) The Distribution and Chemical Quality of Ground Water in Northern Nigeria. Geological Survey of Nigeria. Bulletin No. 36. Authority of the Federal Government of Nigeria, Abuja.

[2] Oparaku, L.A. (2015) Gully Erosion on the Idah-AnkpaPlatean of the Anambra Basin, Nigeria. A Ph.D. Thesis Submitted to the Department of Geography and Planning, University of Jos, Plateau State, Nigeria.

[3] Lal, R. (1990) Soil Erosion in the Tropics: Principles and Management. McGraw Hill, $588 \mathrm{p}$.

[4] Morgan, R.P.C. (2005) Soil Erosion and Conservation. 3rd Edition, Blackwell Publ. Ltd., USA.

[5] Hudec, P.P., Simpson, F., Akpokodje, E.G., Umenweke, M.O. and Ondrasik, M. (1998) Gully Erosion of Coastal Sediments of Nigeria. In: Moore, D. and Hunger, O., Eds., Proceedings of the Eight International Congress, International Association for Engineering Geology and the Environment, Vancouver, 21-25 September 1998, A.A. Balkema, Rotterdam, 1835-1841.

[6] Onuoha, K.M.S. and Uma, K.O. (1988) An Appraisal of Recent Geologic and Hydrologic Hazards in Nigeria. In: Natural and Man-Made Hazards, Kluwer Academic Publishers, The Netherlands, 147-159. https://doi.org/10.1007/978-94-009-1433-9_11

[7] Hudec, P.P., Simpson, F., Akpokodje, E.G. and Umenweke, M.O. (2006) Termination of Gully Processes in Southeastern Nigeria. Proceedings of the Eighth Federal Interagency Sedimentation Conference, Reno, NV. 
[8] Schneidegger, A.E. and Ajakaiye, D.E. (1994) Mass Movement in Hilly Areas with Examples from Nigeria. Natural Hazards, 9, 191-196.

[9] Egboka, B.C.E., Nwankwor, G.I. and Orajaka, I.P. (1990) Implications of Paleo-andNeotectonics in Gully Erosion-Prone Areas of Southeastern Nigeria. Natural Hazards, 3, 219-231.

[10] Oparaku, L.A., Aho, I.M. and Iwar, R.T. (2015) Relative Vulnerability to Gully Erosion of Three Geological Sediments: A Texture-Based Assessment. Journal of Environment and Earth Science, 6, 7-16.

[11] ECAN (1982) Gully Erosion Control Measure for Ankpa Town. Federal Ministry of Agriculture, Abuja.

[12] Oparaku, L.A., Enokela, S.O. and Akpen, G.D. (2015) Gully Erosion-Induced Land Degradation on the Idah-Ankpa Plateau of the Anambra Basin, Nigeria. International Journal of Innovative Research in Science, Engineering and Technology, 4, 6864-6870.

[13] Brice, J.C. (1966) Erosion and Sedimentation in the Loessian-Mantled Great Plains, Madison Greek Drainage. Drainage Basin, Nebraska. Geological Survey Professional Paper. 352-H.

[14] Babalola, O. and Obi, M.E. (1981) Physical Properties of the Acid Sands in Relation to Land Use. In Acid Sands of Southern Nigeria. SSS Special Publication, Monograph No1.

[15] Mckyes, E. (1989) Agricultural Engineering Soil Mechanics. Elsevier Science Publishers, Amsterdam, $291 \mathrm{p}$.

[16] Roloff, G., Bradford, J.M. and Scrivner, C.L. (1981) Gully Development in the Deep Loess Hills Region of Central Missouri. Soil Science Society of America Journal, 45, 119-123. https://doi.org/10.2136/sssaj1981.03615995004500010026x

[17] Obi, M.E. and Asiegbu, B.O. (1980) The physical Properties of some Eroded Soils of Southeastern Nigeria. Soil Science, 130, 39-48. https://doi.org/10.1097/00010694-198007000-00007

[18] Bradford, J.M. and Piest, R.F. (1977) Gully Wall Stability in Loess-Derived Alluvium. Soil Science Society of America Journal, 41, 115-122. https://doi.org/10.2136/sssaj1977.03615995004100010032x 